\title{
Jean-Claude Vallecalle, Messages et ambassades dans l'épopée française médiévale. L'illusion du dialogue
}

\section{G. Matteo Roccati}

\section{CpenEdition}

1 Journals

\section{Édition électronique}

URL : http://journals.openedition.org/studifrancesi/6179

DOI : 10.4000/studifrancesi.6179

ISSN : 2427-5856

Éditeur

Rosenberg \& Sellier

\section{Édition imprimée}

Date de publication : 1 novembre 2010

Pagination : 524

ISSN : 0039-2944

\section{Référence électronique}

G. Matteo Roccati, « Jean-Claude Vallecalle, Messages et ambassades dans l'épopée française médiévale. L'illusion du dialogue », Studi Francesi [En ligne], 162 (LIV | III) | 2010, mis en ligne le 30 novembre 2015, consulté le 13 janvier 2021. URL : http://journals.openedition.org/studifrancesi/6179 ; DOI : https://doi.org/10.4000/studifrancesi.6179

Ce document a été généré automatiquement le 13 janvier 2021.

\section{(c)}

Studi Francesi è distribuita con Licenza Creative Commons Attribuzione - Non commerciale - Non opere derivate 4.0 Internazionale. 


\title{
Jean-Claude Vallecalle, Messages et ambassades dans l'épopée française médiévale. L'illusion du dialogue
}

\author{
G. Matteo Roccati
}

\section{RÉFÉRENCE}

JEAN-CLAUDE VALLECALLE, Messages et ambassades dans l'épopée française médiévale. L'illusion du dialogue, Paris, Honoré Champion éditeur, 2006 («Nouvelle biblio-thèque du Moyen Âge», 82), pp. 630.

1 L'étude est riche, fine, documentée et attentive à l'évolution de son objet dans le temps. Au-delà du motif littéraire - dont est soulignée l'autonomie par rapport à la réalité historique -, elle entend cerner la conception globale de la communication (et la vision du monde) qui le fonde et qui s'exprime dans le genre littéraire épique: celle d'une société féodale régie par les liens clientélaires et familiaux, intolérante, négatrice de l'altérité, où la diplomatie n'est qu'une variante de l'affrontement visant à supprimer l'adversaire. L'ouvrage est organisé en trois parties. La première traite des formes du message (I. «Aspects du message»): de la diversité et des dénominations des messagers, du message comme motif épique, de sa forme orale et écrite, des figures et des règles du jeu diplomatique. Les deux autres parties examinent la nature des messages, en les départageant selon leur destination, à l'extérieur ou à l'intérieur du groupe social. L'étude met l'accent sur ce qu'ils révèlent de la perception que ce dernier a de luimême: d'une part l'affirmation de soi, déniant toute existence à l'autre (II. «Un rêve d'unicité»), qui apparaît dans les messages belliqueux, mensongers (où le messager se confond avec l'espion), ou visant, sans l'avouer, la négociation; d'autre part l'idéal de cohésion sociale, en tension permanente avec les aspirations individuelles des héros (III. «Une volonté d'unité»), sensible dans la convocation des vassaux et les demandes de secours. 
2 Bibliographie (pp. 589-614) et index des auteurs et des œuvres (antérieurs et postérieurs à 1800) complètent le volume. 